\title{
The Inspirations and Resonances Of Art and Art History in Pish Posh, Said Hieronymus Bosch and When Cats Dream
}

\author{
Teya Rosenberg \\ Asst. Professor \\ Southwest Texas State University \\ Note: I have included images from the picture books and art sources discussed \\ in this article, but not all the pictures I refer to have images due to copyright \\ restraints. For the art sources, especially Matisse and Chagall, I recommend \\ Mark Harden's Artchive at www artchivecom
}

Almost any picture book offers references to other visual arts. Illustrators have sources of inspiration: artists, schools or periods of art they admire and refer to in their own art. Alternatively, the artistic influences we perceive in picture books can be simply a result of the fact that although there are many ways of presenting line, form, and color on a page, the possibilities are not infinite. However, there are picture books in which the authors/illustrators do make clear, obvious references, visual or written, to specific artists or periods of art. In some cases, those references are instructional in purpose, meant to educate the reader about the artists or history of art. On the other hand, there are also picture books in which such references are part of a fictional story, and their purpose is less obviously instructional, serving instead as an integral part of the story being told. Such books offer, but do not insist upon, an education in art history and theory for the reader.

The two books I examine, Pish Posh, Said Hieronymus Bosch, words by Nancy Willard, pictures by Leo, Diane, and Lee Dillon, and When Cats Dream by Dav Pilkey, indeed offer many references to art, many allusions and jokes. Neither story requires that the audience know those references, for the stories stand on their own, with verbal and visual texts working together to create entertaining and complete narratives. And yet, as with any reading experience, the more background the reader has, the more depth and resonance a text may assume. Both Pish Posh, Said Hieronymus Bosch and When Cats Dream offer 
encouragement to explore the history of art with their clear and inspired references to artists and art movements of the past.

Pish Posh, Said Hieronymus Bosch states its inspiration very clearly in its title. Throughout the text, besides the obvious naming of the artist, there are playful reminders of the source: in the verbal text there are single word reminders of Bosch's inspiration, the religious themes he captured in his paintings. The visual text continues with the playful reminders: backgrounds and composition are reminiscent of Bosch, and the Dillons have drawn Nancy Willard's Bosch to resemble the self-portraits of the original Bosch. Of course, the most obvious reference lies with the creatures, central to the picture book's story, named by Willard and pictured by the Dillons.

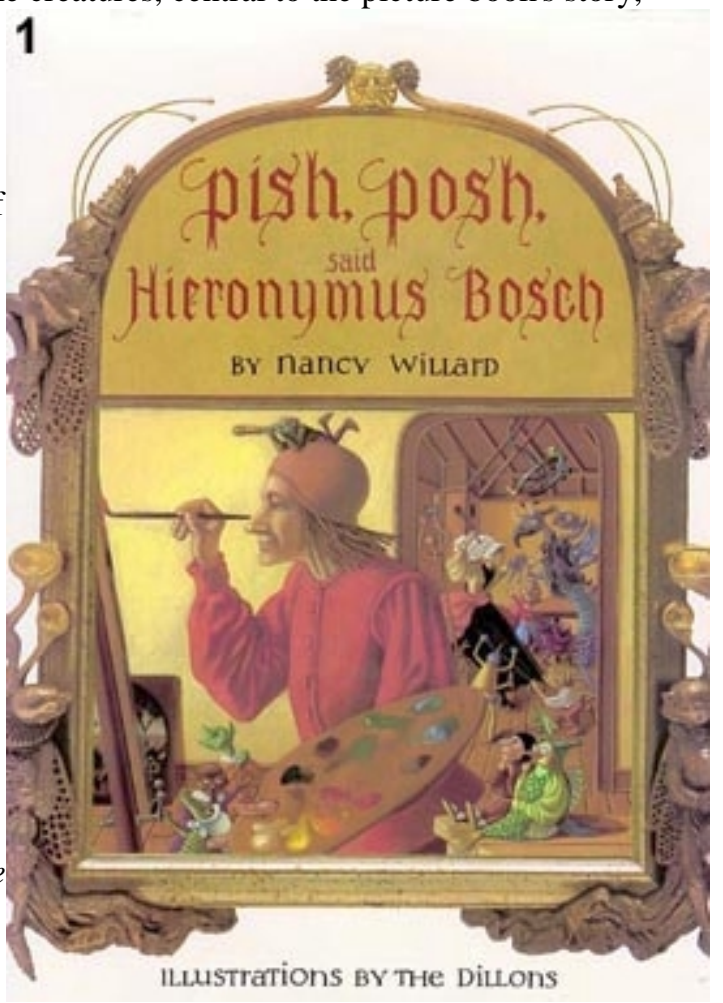

Delights. The story, in short, is of the young woman who keeps Bosch's house and all his odd creatures: "to her fell the job of / feeding them, / weeding them, / stalking them, / calming them, / combing them, / scrubbing and tucking in all of them--" She grows weary of the work and so packs her bag and leaves; but "a mole in a habit, / a thistledown rabbit / a troop of jackdaws, / a three-legged dish, / the pickle-winged fish, and a head wearing claws" who follow her, persuade her to return to Bosch, who then declares his intention to change: "forever and ever, my nibble, 
my nosh, till death do us part," said Hieronymus Bosch." Yet, just as fifteenth-century Bosch's subject matter and visualizations convey moods and themes that reflect a concern of the time: the nature of sin and the potential for ending up in hell, Pish Posh, Said Hieronymus Bosch reflects a twentieth-century concern: the woman's role in the home. Rather than the pessimism and doom of Bosch's work and the impending tragedy of post-lapsarian life, we get instead the housekeeper and surrogate mother dealing with the foibles of a preoccupied male and demanding offspring presented as comedy-romance. Instead of the Bible, we have the Sound of Music, only more fun.

Although the subject matter of Bosch plays no major role in Pish Posh, Said Hieronymus Bosch, there are minor notes that reflect the artist's work. Verbally, Willard does not completely abandon the religious milieu in which Bosch worked. There are references, admittedly slight, to the prevalence of the religious nature of life in the fifteenth century: the creatures include a "pear-headed priest" and a "mole in a habit"; the young woman sees the nuns as an alternative to her hectic life: "I'd rather be bored and hang out their laundry in sight of the Lord," which seems to suggest that Bosch's household may not be "in sight of the Lord." The funniest reference comes, I think, with Hieronymus Bosch's reaction to the

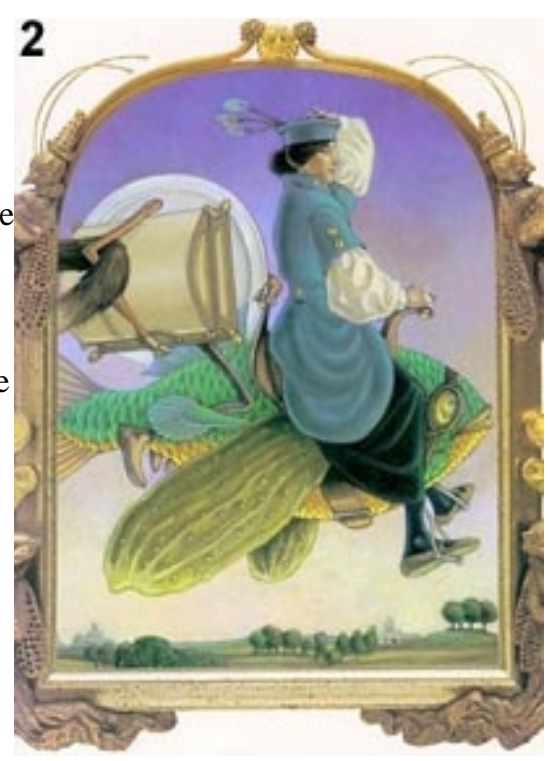
young woman's return: "Hieronymus rose from a harrowing night, / Saw salvation coming, and crowed with delight." In these lines, we are reminded of the religious themes common in Renaissance painting. 
Most obviously connected to Bosch are, however, Willard's creatures which blend characteristics of humans, animals, and inanimate objects. Surprisingly, when one goes carefully through the written text, there are not that many truly odd creatures. Most of the humour comes from animals or objects doing things they normally would not do: Cats chasing cucumbers, lizards doing laundry; larks mending clothes, and so on. The truly odd creatures such as the pickle-winged
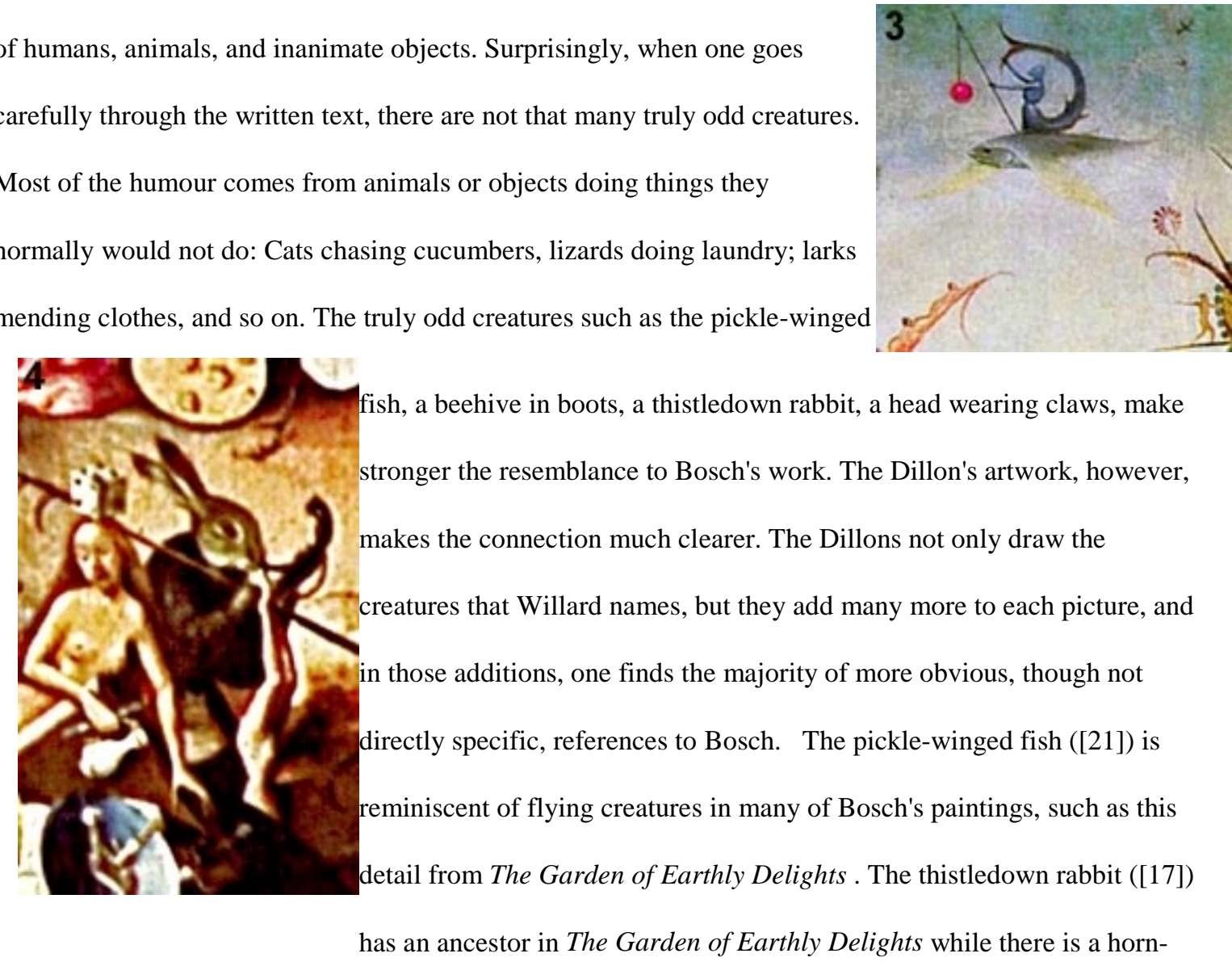

nosed something ([23]) that has some familial resemblance to an earlier character in The Temptation of St.

Anthony. These similarities provide the viewer who knows Bosch with familiar points of reference; however, they can also work the opposite the viewer who does not know Bosch but does know Pish Posh, Said Hieronymus Bosch will have those points of reference with which to view Bosch, thus creating a frame of reference which can make the viewing

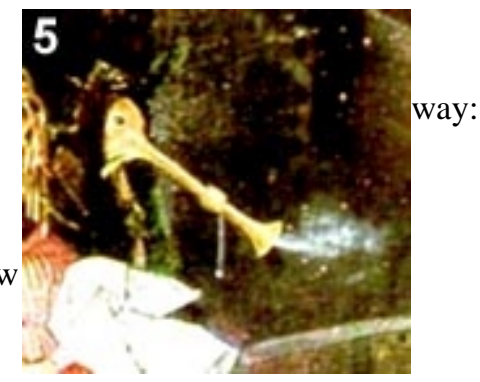
experience more meaningful. 
The Dillons' additions also create the busy-ness that both parallels Bosch's work and supports the overwhelming nature of the young woman's situation. If we compare this picture with a Bosch painting, we can see that the Dillons have captured the essence of Bosch's multitudes as opposed to mimicking them

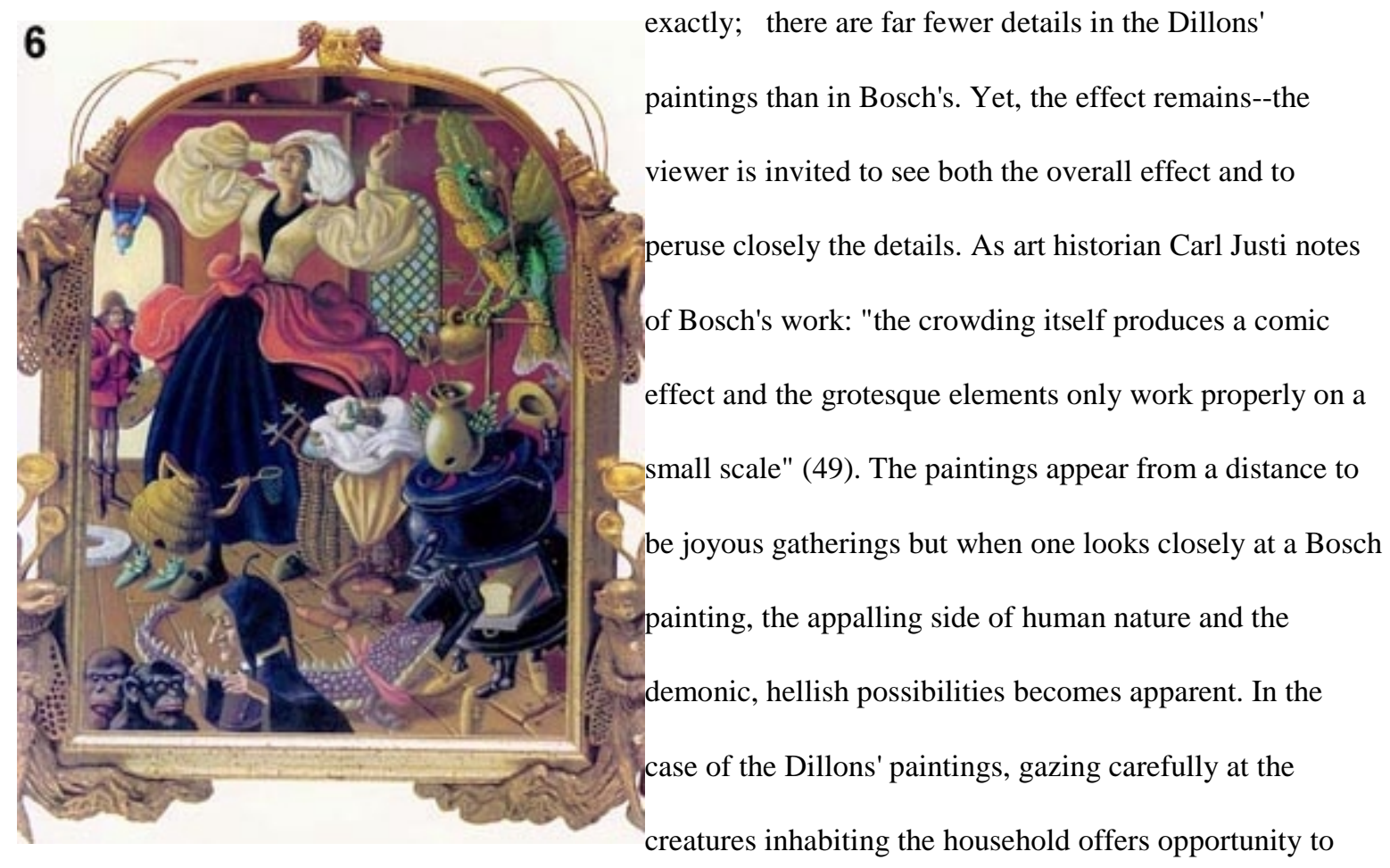

form an attachment to these creatures, a response that prepares for the young woman's eventual decision to return to Bosch's home, for although the creatures: "are not what I wished for," still, she has a fondness for them ([19]). 


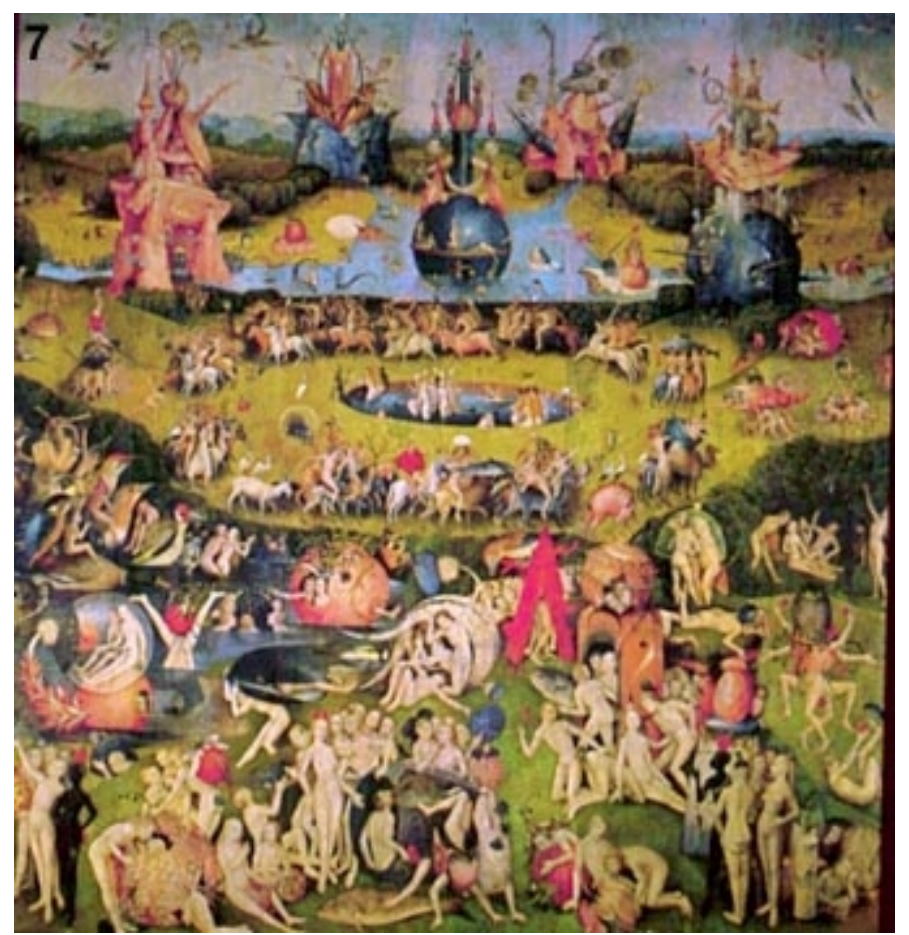

Other elements of the Dillons' paintings work to remind of Bosch himself and of the Northern

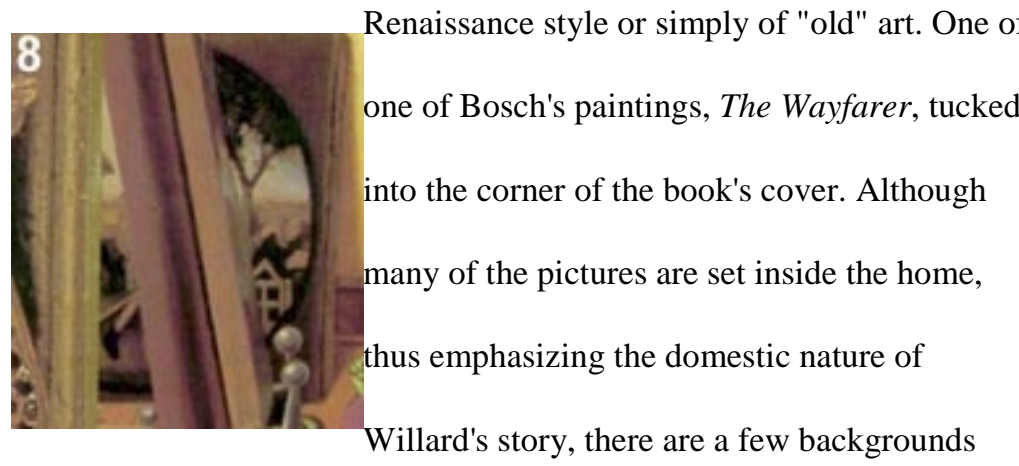

which remind one of the background landscapes in many paintings from

the Netherlands during the Renaissance $([7,21])$; where, in Bosch's work,

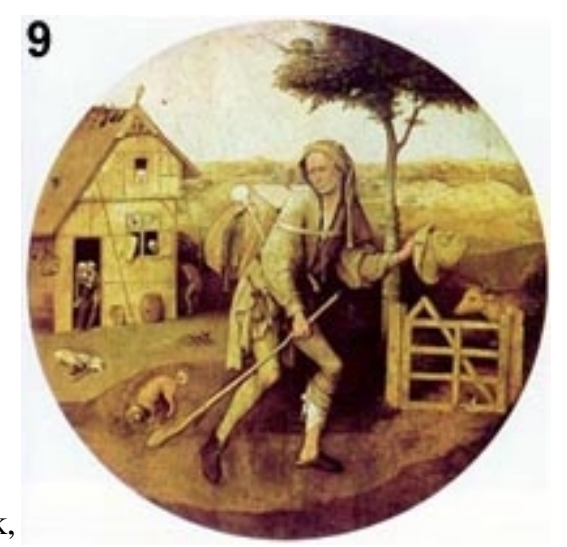

those backgrounds serve to announce the depth and width of the topic, in

the Dillons' they serve to remind us of Bosch. As well, the frames, created by the Dillons' son Lee, serve to remind us of the connection to art. Finally, the hand lettering of the text in sepia color is reminiscent of medieval scripts--an anachronism but nonetheless signalling a connection to the past. 
What to make, then, of these references to Hieronymus Bosch? I have found over the past three or four years of giving students in my children's literature classes opportunity to examine Pish Posh, Said Hieronymus Bosch, that many initially react negatively to the pictures, finding them too dark, scary, and discomforting. Not until we look closely at some Bosch pictures do they perceive the softened, humorous quality of the Dillons' interpretations. So I think we can say that the Dillons do capture the essence and spirit of Bosch's work, the unsettling quality that so fascinates we of the twentieth century about the work of the fifteenth-century painter. Thus, Pish Posh Said Hieronymus Bosch is a gentle introduction to a fascinating artist as well as an amusing account of dealing with an active household.

When Cats Dream by Dav Pilkey does not have the same focused references to its inspirations as Pish Posh, Said Hieronymus Bosch does. Instead, it has a pastiche of references to specific works such as The Artist's Mother by Whistler, to specific artists such as Marc Chagall and Henri Rousseau, and to artistic movements and styles such as Cubism, Fauvism, and Naive or Primitive art. There are also references to film and cartoon, making When Cats Dream a tribute to the visual arts in general. The uniting thread for all the references lies in the title: dreams and cats. Pilkey has chosen visual elements from artists, works, and styles all of which focus upon the nature of dreams or upon expressing inner life; most of the specific artists have also dealt with cats. The book thus is a sort of long visual joke as well as an homage to art, artists, and, of course, to cats.

The frame of the story, which establishes the nature of the waking life of cats, offers a number of different visual references. Of course, an obvious reference is to the movie version of The Wizard of Oz:

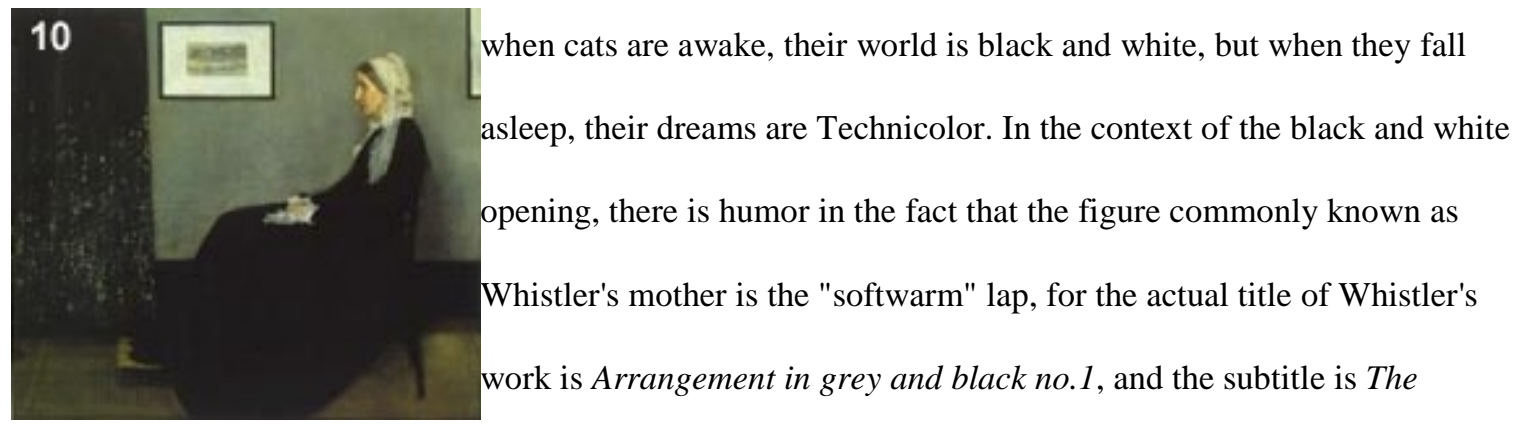

Artist's Mother. Whistler's intention was not so much to represent his 
mother, but to explore the formal qualities of the two dimensional plane, an exploration that is key to the later Cubist painters. It is thus ironic that the picture has become such an icon of motherhood, but Pilkey uses both the cultural and the artistic elements of the work: the maternal connects with the comfort the cat finds and the artistic is consistent with the visual representation of the cat's awake life. Mona Lisa as the 'softwarm' lap at the end of the book also plays with the maternal connotations of the painting; while that painting is not in black and white, its colors are subdued, but there seems to be little more to that reference than its maternal aspect.

The opening in black and white and the transition to color plays on the popular conventions of the dream vision and on the idea that cats see in black and white, but it also connects with the history of the artist whose influence is most apparent in the first half of this book: Marc Chagall, who is noted for combining the monochromatic, geometric elements of early Cubism with the colors of Fauvism. In fact, the sequence of pictures as the cat enters its dream is a sort of mini-history of art in the first two decades of the twentieth century. In the view of Whistler's mother as the cat enters its dream, she has been transformed into a sort of punk-Picasso figure ([7-8])--the Cubist method of placing all the subject on the two dimensional plane is apparent in her face and hands, while the blue surroundings remind us of Picasso's Blue Period, although only in a superficial manner, since the tone of blue and the subject matter have little to do with that period of Picasso's work. The cat's entry to the dream world is first connected, through color and line, to the world of the Picasso figure. The cat than emerges in a world full of dancing cats ([9-10) that remind one of Matisse's Dance \#1 in terms of movement of the figures as well as with the colors. Finally, the cats are part of a picture which has direct references to I and the Village ([11-12), one of Chagall's earliest famous paintings that employs Cubist (Picasso) and Fauvist (Matisse) elements: the use of geometrical planes combined with brilliant colors, plus Chagall's own inversions of the world and magical flowers. Thus, Pilkey simultaneously presents the process of entering the world of dreams and records an artistic movement that lead to the visual representations of dreams, for a critic notes that "Chagall's historic achievement" is "that, immediately perceiving the evocative possibilities of the Cubist picture, he opened it 
up to embrace the irrational world--the imagery of the unconscious, of dreams, and of memory" (Haftmann 18).

Chagall's work presents memories of his life in Russia, elements of Russian folktales, religious iconography amongst other things: in short, the elements that composed his inner life and his identity; cats, of course, have entirely different concerns, as Pilkey's written text and the visual text emphasize.

Perpetually open back doors ([11]) and dogs who never wake up ([13]) are parts of cats' dreams. The words tell us that swimming with fishes ([9]) and flying ([15]) are activities the cats dream about and the pictures show birds and fish throughout. Those birds and fish are drawn in a childlike manner, which is also notable in the cat in the left hand corner of the cover who owes less to any famous artist and more to crayon drawings committed to bedroom walls by the very young: truly avant-garde graffiti artists, if we think of "garde" as a reference to being keepers or guardians; that is, to being adults. Pilkey has said that one of his inspirations is the drawings children send him because of their willingness to do anything in a picture, including "make their trees purple and yellow" or the sky "green with red stripes" (Something About the Author 186). He adds: "of course, you know that one day an art teacher is going to grab

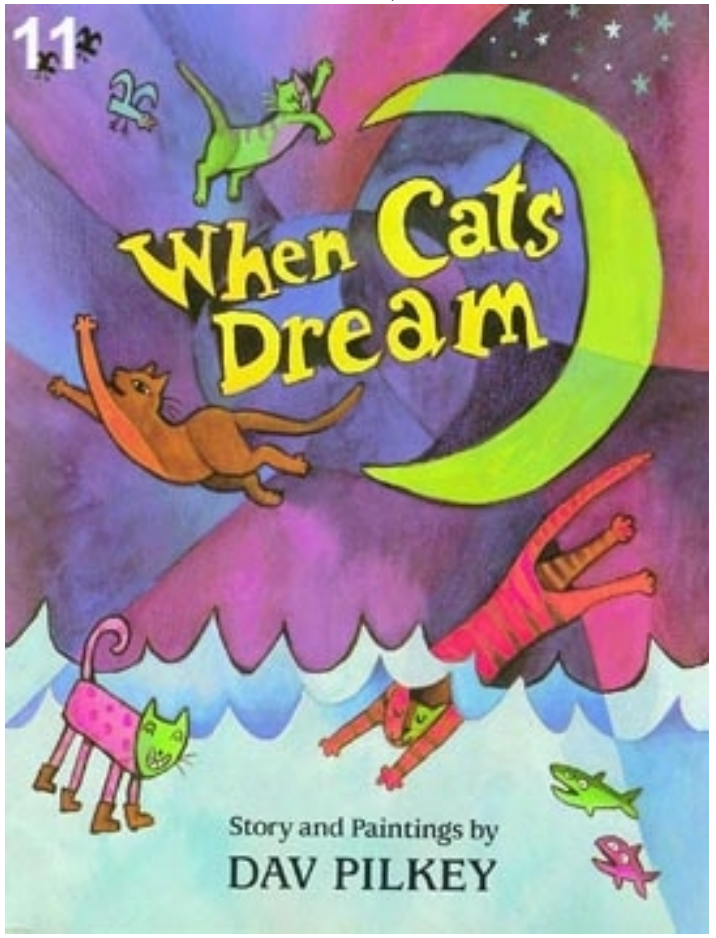
ahold of these kids and turn them all into accountants, but while they are still fresh and naive, children can create some of the liveliest and most beautiful art there is" (186). Of course, capturing or recapturing this freshness and liveliness is part of what drove artists like Matisse and Chagall, and also their contemporaries such as Kandinsky and Miró. Childlike depiction of cats show up a number of times in the story $([12,18,23])$, creating a link to the prospective audience of the picture book, but also providing an example of truly naive art, and thus providing a humorous link between 
the modified Cubism of Chagall, and the Naive or primitivist art of Henri Rousseau, the second major influence noticeable in When Cats Dream.

As the cats finish Dionysion revels of swimming, flying, and dancing, they "find their way to the jungle" (18), a jungle clearly based on those of Rousseau's paintings [17-18]. The cats in this jungle stalk, hunt, and hide in the leafy, luxuriant undergrowth. An obvious reference is Rousseau's painting The Dream because of its title and because of the two cats peering from the centre of the picture just as a cat on the far

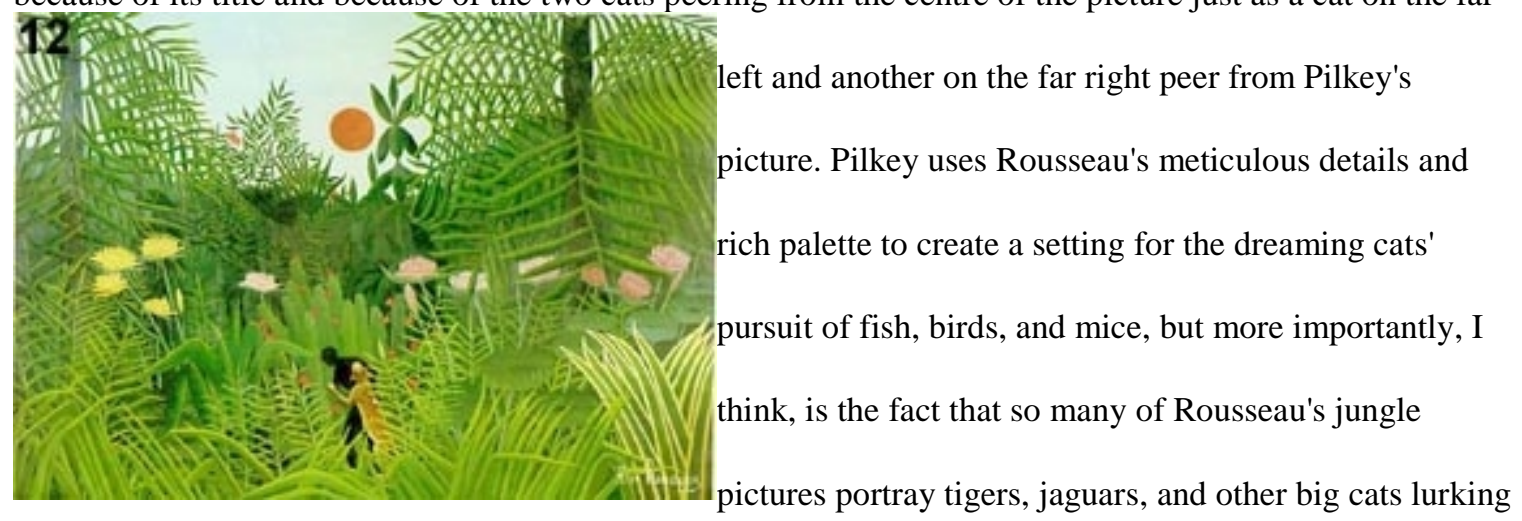

in the undergrowth or being ferocious as they eat game or people. The jungle scene is the turning point for Pilkey's story. After that, the cat slowly returns to the waking world. Thus, I think we can see the jungle scene as the heart of cat darkness and primitiveness, an allusion to the ferocious ancestry that lies at the heart of every cat sleeping in a "softwarm" lap. Pilkey's paintings draw on the content of Rousseau's jungle pictures, but also play with the overall category or style of Rousseau's work, Naive or Primitive art, creating resonances for the narrative.

This idea of resonance is ultimately the point of noting the art references in When Cats Dream. The story stands well on its own; the convention of depicting life in black and white and dreams in color is a common enough signal for most readers; the point that dreams are outlets for imagination is enough to explain the odd things the cats are doing and the wild use of geometrical planes of color. Visually, the pictures are pleasing: the colors are not jarring and the Cubist elements toned down rather than taken to their extremes. And yet, once one knows the sources for many of the techniques and images and begins to understand how Pilkey manipulates them to support his tale of cats' dreams, the story takes on a depth and, 
more importantly, a humour. Pilkey interprets the techniques and ideas of early twentieth-century art and communicates the love of color, of shape, and of the musicality so much a part of particularly Chagall and Matisse.

When we step back from When Cats Dream and think about the two books I have focused on, we come back to the question of the significance of references to visual arts in children's picture books. What is the point of such references in works for an audience that probably will not get all the jokes? W.

Nikola-Lisa has noted, in "I Spy: A Place for the Arts in Children's Picture-Books," that there are many books on the market which introduce art to children; many of them are non-fiction histories or explanations of art styles or particular artists. Others use art as part of a game, such as Micklethwaite's I Spy books. Such books have a specifically didactic purpose. The two I discuss, which belong to a category Nikola-Lisa calls "art fantasy" (53), provide stories that can stand independent of their source references; people don't have to learn anything if they don't want to. Yet, at the same time, these entertaining stories encourage looking farther and figuring out the references; they are an enticement to learning. Furthermore, I think stories such as these resemble the many parodies available in picture books today, books like The Three Little Wolves, or The Stinky Cheeseman, and both groups present a similar puzzle: should the reader come to these texts already knowing the sources or can the stories be an introduction to learning about the sources? The answer is yes. The process of learning is not linear but a constant circling and backtracking. "Getting the joke" or realizing a source can be just as rewarding if it occurs well after one's first encounter with a story then if it occurs at the moment of first contact. Pish Posh Said Hieronymus Bosch and When Cats Dream are books to grow with, invitations to explore the world of painting, painters, and art movements.

\section{$\underline{\text { Works Cited }}$}

Beagle, Peter S. The Garden of Earthly Delights. New York: Viking, 1982.

Goldwater, Robert. Primitivism in Modern Art. Enlarged ed. Cambridge, MA and London: Harvard UP (Belknap), 1986.

Haftmann, Werner. Marc Chagall. Trans. Heinrich Baumann and Alexis Brown. New York: Harry N. Abrams, [1973].

Janson, H. W. and Anthony F. Janson. History of Art. 5th ed. rev. New York: Prentice Hall and 
Harry N. Abrams, 1997.

Justi, Carl. "The Works of Hieronymus Bosch in Spain." Bosch in Perspective. Ed. James Snyder. Englewood Cliffs, NJ: Prentice-Hall, 1973. 44-56.

"Leo Dillon 1933- Diane Dillon 1933-." Children's Literature Review 44 (1997): 17-49.

Le Pichon, Yann. The World of Henri Rousseau. Trans. Joachim Neugroschel. New York: Viking, 1982.

Leymarie, Jean, et al. Henri Matisse. Berkeley and Los Angeles: U of California P, 1966.

Nikola-Lisa, W. "I Spy: A Place for the Arts in Children's Picture-Books." Journal of Children's

Literature. 21.2 (1995): 52-56.

"Pilkey, Dav 1966-." Something About the Author. 68 (1992): 185-187.

Pilkey, Dav. When Cats Dream. New York: Orchard, 1992.

Piper, David, ed. Random House Library of Painting and Sculpture. vols 1-4. New York: Random, 1981. Snyder, James, ed. Bosch in Perspective. Englewoods, NJ: Prentice-Hall, 1973.

Schmeller, Alfred. Cubism. Trans. Hilda Spiel. New York: Crown, [195-].

Vallier, Dora. Henri Rousseau. New York: Harry N. Abrams, [1964].

Willard, Nancy 1936-." Something About the Author 71 (1993): 210-213.

\section{Notes on graphics}

1. From Pish Posh, Said Hieronymus Bosch. Illustrations copyright () 1991 by Diane and Leo Dillon, reproduced by permission of Harcourt, Inc. This material may not be reproduced, stored in retrieval system, or transmitted in any form or by any means without the prior written permission of the publisher.

2. From Pish Posh, Said Hieronymus Bosch. Illustrations copyright (@ 1991 by Diane and Leo Dillon, reproduced by permission of Harcourt, Inc. This material may not be reproduced, stored in retrieval system, or transmitted in any form or by any means without the prior written permission of the publisher.

3. Detail from TheGarden of Earthly Delights by Hieronymus Bosch. Madrid, Museo del Prado

4. Detail from The Garden of Earthly Delights—right wing, Hell by Hieronymus Bosch. Madrid, Museo del Prado.

5. Detail from Temptation of St. Anthony by Hieronymus Bosch. Lisbon, Museu Nacionel de Arte Antiga.

6. From Pish Posh, Said Hieronymus Bosch. Illustrations copyright $(91991$ by Diane and Leo Dillon, reproduced by permission of Harcourt, Inc. This material may not be reproduced, stored in retrieval system, or transmitted in any form or by any means without the prior written permission of the publisher.

7. The Garden of Earthly Delights by Hieronymus Bosch. Madrid, Museo del Prado.

8. Detail from cover of Pish Posh, Said Hieronymus Bosch. Illustrations copyright $\odot 1991$ by Diane and Leo Dillon. 
9. The Wayfarer by Hieronymus Bosch. Rotterdam, Museum Boymans-van Beuningen

10. Arrangement in Grey and Black No.1: The Artist's Mother by James MacNeill Whistler. Musée d'Orsay, Paris.

11. When Cats Dream by Dav Pilkey.

12. Negro Attacked by Jaguar by Henri Rousseau. Basle, Kunstmuseum. 